\title{
Alterations in strength of the shoulder rotators in young elite swimmers
}

\author{
Alteração da força dos rotadores do ombro \\ em jovens nadadores de elite
}

\section{Gustavo Antonio Meliscki ${ }^{[a]}$, Luciana Zaranza Monteiro ${ }^{[a]}$, Marco Antonio Furumoto ${ }^{[b]}$, Guilherme Henrique Ramos Lopes ${ }^{[\mathrm{c}]}$, Estela Cristina Carneseca ${ }^{[\mathrm{a}]}$, Everaldo Encide de Vasconcelos ${ }^{[\mathrm{d}]^{*}}$}

[a] Faculdade de Medicina de Ribeirão Preto da Universidade de São Paulo (FMRP-USP), Ribeirão Preto, SP, Brazil

[b] Universidade de Ribeirão Preto (UNAERP), Ribeirão Preto, SP, Brazil

[c] Universidade de Brasília (UNB), Brasília, DF, Brazil

[d] Centro Universitário Barão de Mauá, Ribeirão Preto, SP, Brazil

\begin{abstract}
Introduction: Shoulder muscle strength imbalance is considered a risk factor for shoulder injuries in athletes, especially in sports involving arm movements above the head. Objective: To assess the strength of the external rotators (ER) and internal rotators (IR) of the shoulder in elite swimmers, to determine possible differences between the dominant and non-dominant limbs, and to calculate the shoulder IR/ER ratio. Methods: Fifteen athletes participated in the study from age $20 \pm 2$ years, mass of $76 \pm 4 \mathrm{~kg}$, stature of 1.83 $\pm 4 \mathrm{~cm}$, and BMI of $22 \pm 1 \mathrm{~kg} / \mathrm{m}^{2}$. Duration of practice of $10.74 \pm 4.03$ years; training frequency $5.95 \pm 0.22$ days/week, $2.07 \pm 0.41$ hours/day; and weekly number of meters swum 34.905. An isometric dynamometer (Globus Ergo System $®$, Codognè, Italy) was used to assess ER and IR strength. Data were analyzed using descriptive statistics (mean and standard deviation), paired-sample t-test, Pearson's correlation coefficient and the Statistical Package for Social Sciences software (SPSS), version 16.0. Results: IR and ER strength
\end{abstract}

\footnotetext{
GAM: MS, e-mail: gustavo.meliscki@gmail.com LZM: PhD, e-mail: lucianazaranza@hotmail.com MAF: MS, e-mail: mafurumoto@yahoo.com.br GHRL: MS, e-mail: guilhermelopes@hotmail.com ECC: MS, e-mail: estela.federal@gmail.com EEV: MS, e-mail: gut4o@hotmail.com
} 
was lower in the left than in the right shoulder of the swimmers $(\mathrm{p}<0.05)$. Additionally, ER strength ratio was higher than IR strength ratio ( $p<0.05)$. Conclusion: The results showed that the swimmers had an alteration of the shoulder ER/IR ratio, especially in the dominant limb.

Keywords: Muscle Strength. Rotator Cuff. Swimming.

\section{Resumo}

Introdução: $O$ desequilíbrio da força da musculatura do ombro é considerado um fator de risco para algumas lesões no ombro dos atletas, especialmente em esportes que envolvem movimentos acima do nível da cabeça. Objetivo: Avaliar a força da musculatura rotadora externa (RE) e rotadora interna (RI) do ombro em nadadores de elite, verificar possíveis diferenças entre o membro dominante e o não-dominante e determinar a relação RE/RI de ombro. Métodos: Participaram 15 atletas (idade: $20 \pm 2$ anos, peso: $76 \pm 4 \mathrm{~kg}$, estatura: 1,83 $\pm 4 \mathrm{~cm}, I M C: 22 \pm 1 \mathrm{~kg} / \mathrm{m} 2$ ), tempo de prática de 10,74 $\pm 4,03$ anos, frequência de treino/semana $=5,95 \pm 0,22$ vezes, horas $/$ dia $=2,07 \pm 0,41$ hs e metragem semanal $=34.905 \mathrm{~m}$. Para avaliar a força dos $R E$ e RI foi utilizado um dinamômetro isométrico (Globus Ergo System ${ }^{\circledR}$, Globus Itália). Os dados foram analisados através da estatística descritiva (média e desvio padrão), pelo Teste t para amostras pareadas e pela Correlação de Pearson (r), por meio do programa pelo programa SPSS versão 16.0. Resultados: Em relação à força dos rotadores, os nadadores apresentaram uma força menor nos RI e RE do ombro esquerdo quando comparado ao ombro direito $(p<0,05)$. A relação dos $R E$ foi maior que a relação da força dos $R I(p<0,05)$. Conclusão: Os resultados revelaram que os nadadores apresentaram uma alteração da relação $R E / R I$, principalmente no membro dominante.

Palavras-chave: Força Muscular. Manguito Rotador. Natação

\section{Introduction}

The shoulder internal and external rotator (IR/ER) muscles play an important stabilizing and mobility role in the glenohumeral joint, especially in athletes who perform overhead motions $(1,2)$.

Competitive swimming is one of the most popular participation sports in the United States and participation has been growing around the world (3). However, as in any performance-based sport, injuries can happen to the athlete.

Competitive swimmers usually have overuse injuries, especially in the shoulders $(4,5)$. Studies have shown that $38 \%$ to $75 \%$ of high-performance swimmers have already had at least one episode of shoulder pain that forced them to abandon training or a competition $(6,7,8)$. Most of these injuries is associated with the athlete's shoulder IR or ER muscles, as they cover the glenohumeral joint, afford an important protection to this joint, and help improve the performance of highperformance swimmers (1). However, biomechanical changes caused by muscle strength imbalance between shoulder internal and external rotators may lead to an increased incidence of injuries to the shoulder of athletes $(1,9)$.

The ER/IR ratio has been the subject of several studies in various sports. Over the years a change in what are considered to be "ideal" values for an optimal balance of the glenohumeral joint has been discussed. Studies conducted in the 1980s and 1990s considered a ER/IR ratio of $66 \%$ to be ideal so that the rotator cuff muscles could balance the glenohumeral joint, thus promoting an increase in the subacromial space $(7,10,11)$. These values have currently changed. According to some authors, the ideal balance would only be achieved after reaching a ER/IR ratio between $66 \%$ and $75 \%(12,13)$. In addition, a difference of up to $10 \%$ of maximum strength between limbs would be deemed "acceptable" or "normal" (14).

Even though very similar movements are produced in both sides of the body during swimming, some changes and imbalances can be found $(15,16)$. These can 
cause the athlete not to reach the desired performance level or may represent risk factors for musculoskeletal injuries. However, to our knowledge, there are no normative data for young adult swimmers, only one study that has assessed isokinetic strength in pubescent swimmers. Since there seems to exist a relationship between low levels of unilateral shoulder proportions and potential injuries, and there are no normative data for young adult swimmers, the aim of this study was to assess the isometric performance of the shoulder ER and IR muscles, comparing the right and the left sides, and to identify the shoulder ER/IR ratio in high-performance swimmers. In Brazil, there are very few published studies on certain issues related to competitive swimming. Thus, further studies are warranted.

\section{Methods}

This descriptive, cross-sectional study was conducted in the second half of 2010 with the elite swimming team of the University of Ribeirão Preto (UNAERP), SP, Brazil. We randomly selected 15 of the 20 athletes of the UNAERP team. Inclusion criteria were: voluntary participation in the study, male gender, no musculoskeletal injury, having the necessary performance level to participate in the Brazilian Swimming Championship (being, thus, considered an elite athlete). All athletes agreed to participate in the study on a voluntary basis. The research project was approved by the Ethics Committee for Research with Human Beings of the University of Ribeirão Preto (UNAERP) - protocol number 066/2010. All participants signed an informed consent, according to Resolution 196/96 of the National Health Council. Volunteers were informed that they were free to participate or not in the study and to leave the study at any time.

After signing the consent form, the athletes were taken to a room where they were to be anthropometrically assessed. In each individual, a thorough assessment was made in the morning before swimming training. Next, the participants were instructed about the assessment of the shoulder ER and IR muscles using an isometric dynamometer (Globus Ergo System ${ }^{\circledR}$ - Codognè, Italy) (17).

Body mass was measured to the nearest $0.1 \mathrm{~kg}$ using a portable digital scale (Filizola ${ }^{\circledR}$, Sao Paulo, Brazil) with a maximum capacity of $150 \mathrm{~kg}$. Height was measured once with an inelastic tape. Body Mass Index (BMI) was determined as body weight divided by height squared (kg/m2) (18).
The maximal isometric strength of the shoulder rotators was measured using an isometric dynamometer (Globus Ergo System ${ }^{\circledR}$ - Codognè, Italy). In some studies, such as the one conducted by Leite and Nonaka (19), investigated the effects of flexibility training on muscle strength in 25 male volunteers using a dynamometer of this type. Sousa et al. (20) have also assessed the muscle strength of shoulder flexors using the aforementined dynamometer. All athletes were instructed about their positioning during assessment (position and height of the torque wrench, position and height of the seat, lever arm length) and about the test values (isometric torque of the ER and IR muscles of both shoulders).

Prior to testing, participants performed a warm-up consisting of active arm movements, followed by stretching exercises for the shoulder muscles. After warm-up, participants were positioned in the dynamometer and asked to remain seated with their back against the chair and the contralateral upper limb resting on their chest, in order to avoid compensatory movements of the trunk during the test. Participants were also asked to keep both of their legs suspended to avoid compensatory movements during the tests (21).

The shoulder was elevated to $30^{\circ}$ in the scapular plane and kept in neutral rotation, with the elbow flexed to $90^{\circ}$ and the forearm in neutral position. After positioning of the subject, we checked the alignment of the mechanical and anatomical axes. The upper arm and forearm were attached to the resistance arm using the stabilizing device. Participants were also told to firmly hold the device handle during testing (21).

After the tests, the assessor passively demonstrated the direction of the movement required for the assessment.

Two submaximal isometric contractions served to familiarize the subjects with the test procedure. After this adjustment phase, the gravity correction value was determined by asking the participant to relax the limb attached to the resistance arm and recording the torque created by the weight of the limb. After the gravity correction value was recorded, the digital display was reset to zero and the test was started. During the test, subjects performed three maximal isometric efforts of 5 seconds and the peak of each contraction was recorded ( $\mathrm{Nm})$. There was a 10-second rest interval between each effort. During the procedure, participants were verbally guided using commands such as "attention", "contract", "strength, strength, strength", "relax".

The normality of the distribution was tested using the Shapiro-Wilk normality test. Data were analyzed 
using descriptive statistics (mean and standard deviation), the t test for paired samples and Pearson's correlation coefficient (which analyzed the correlation between internal and external rotator muscles strength in the right and left shoulders of the swimmers). Participants were also asked about their handedness. Data were analyzed using the Statistical Package for Social Sciences software (SPSS) version 16.0 for Windows. The significance level was set at $\mathrm{p}<$ 0.05 . An external-to-internal rotator muscles strength (ER/IR) ratio $>0.66$ was considered adequate.

\section{Results}

Sample characteristics are shown in Table 1. Of note, all athletes met the inclusion criteria and were in the age group 18 - 25 years, the predominant age group of elite athletes.

Table 1 - Characteristics of the study participants $(n=15)$

\begin{tabular}{lc}
\hline Age (years) & $20.5 \pm 2.47$ \\
Body mass $\mathbf{( k g )}$ & $76.6 \pm 4.75$ \\
Height $(\mathbf{c m})$ & $183.1 \pm 4.92$ \\
BMI (kg/m²) & $22.80 \pm 1.10$ \\
\hline Duration of practice (in years) & $8.2 \pm 1.2$ \\
\hline
\end{tabular}

Figure 1 illustrates the graph representation of the shoulder IR strength in the swimmers. IR strength was lower in the left shoulder when compared to the right shoulder, but no significant difference was found. The difference between limbs was also within normal limits (up to 10\%). All athletes were right-handed.

Our results have shown an average difference of $3 \%$ between shoulder internal rotators. Analyzing only these data, we might conclude that swimming is a sport of symmetrical proportions, in which the propulsion movement performed by both arms promotes an almost perfect muscle balance, which would prevent many injuries.

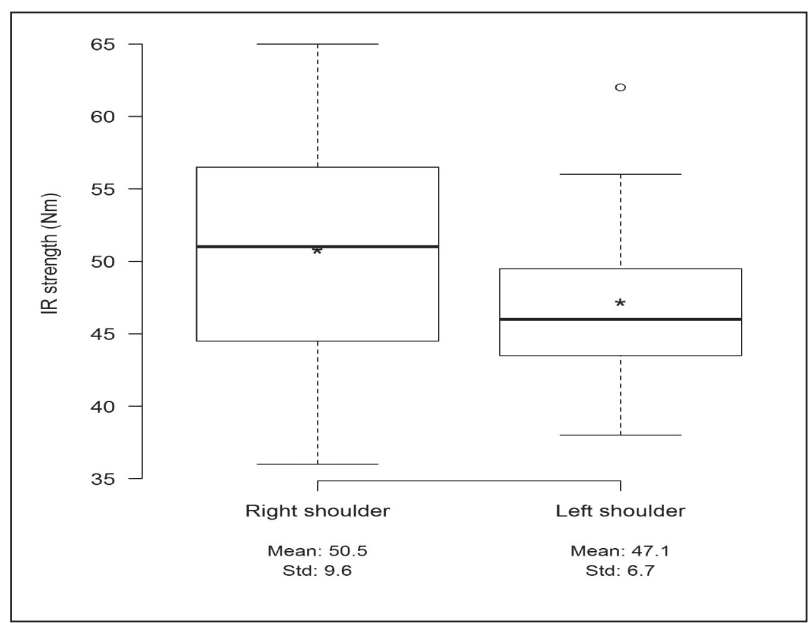

Figure 1 - Comparison between right and left shoulder IR strength in swimmers.

Figure 2 illustrates the graph representation of the shoulder ER strength in the swimmers. ER strength was lower in the right shoulder when compared to the left shoulder, but no significant difference was found.

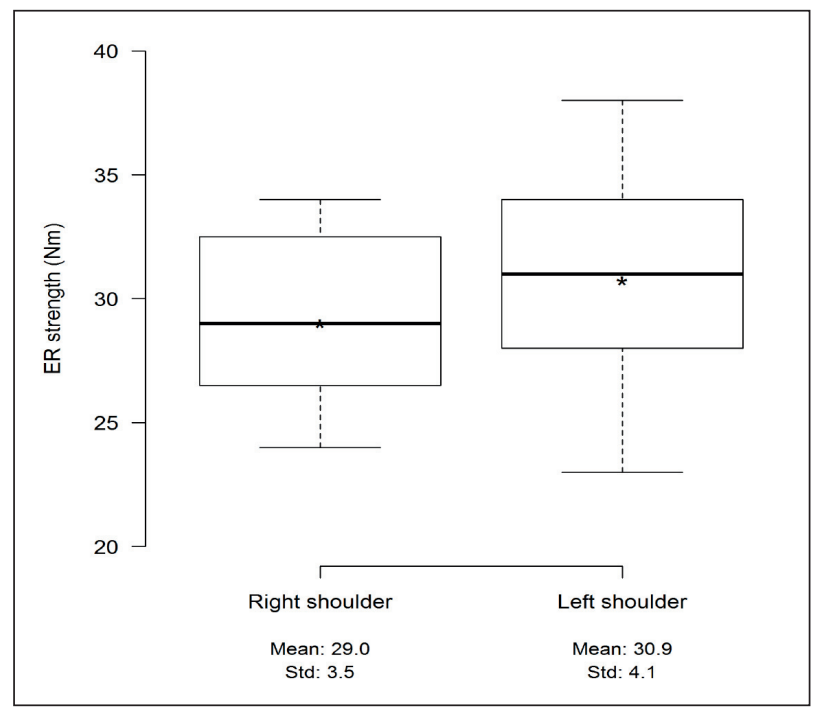

Figure 2 - Comparison between right and left shoulder ER strength in swimmers.

Figure 3 illustrates the graph representation of the right and left shoulder ER/IR strength ratio. We found that the swimmers had a lower ER/IR strength ratio in the right shoulder. Although the difference between limbs was within the normal range (10\%), it caused a significant difference when compared to the left shoulder. 


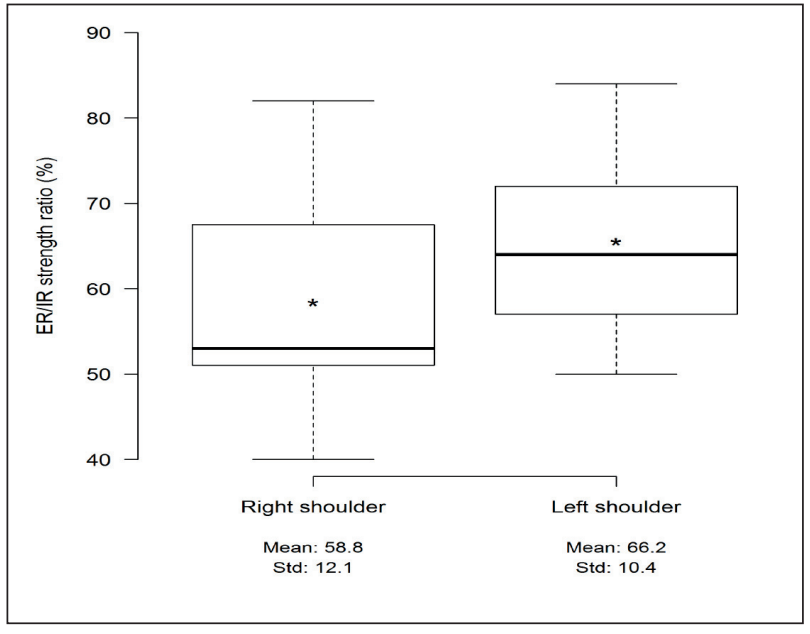

Figure 3 - Comparison between right and left shoulder ER/IR strength ratio in swimmers $\left({ }^{*} p<0.05\right)$.

Finally, Figure 4 shows a dispersion diagram of the ER/IR ratio in the swimmers.

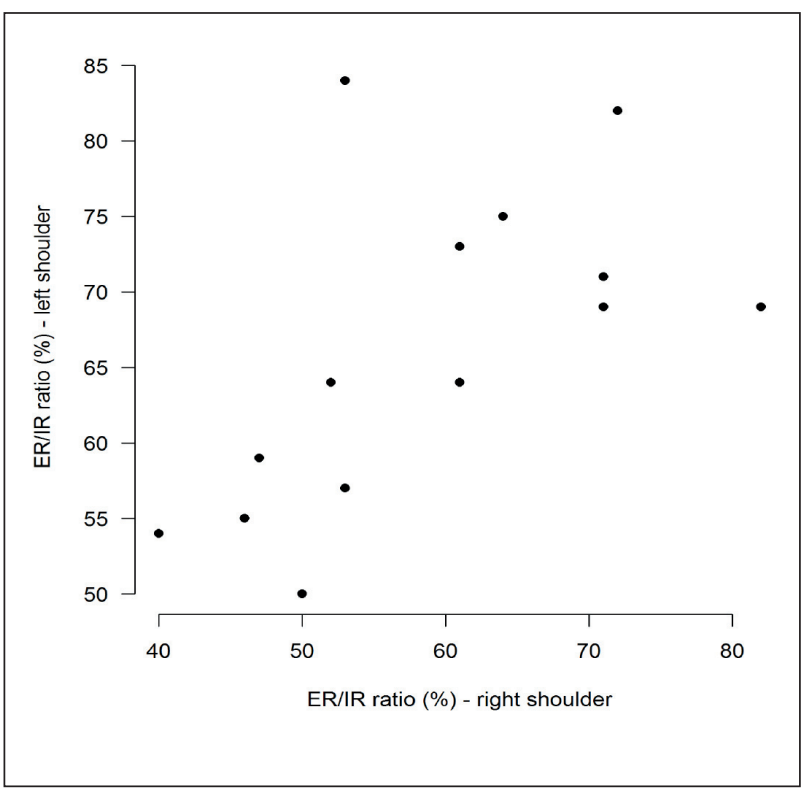

Figure 4 - Dispersion diagram of the right and left shoulder $E R / I R$ ratio in the swimmers $(r=0.62 ; p<0.05)$.

\section{Discussion}

Muscle balance assessment is used in several studies, both in the field of sports (22 - 25) and in the field of health in general (26 - 28). This shows the high reliability and applicability of the tests used. We found that swimmers had lower internal and external rotator strength values in the left shoulder compared to the right shoulder, and the ER strength ratio was higher than the IR strength ratio.

According to the isokinetic test for the lower limbs, the assessment of a limb in relation to its contralateral homologue forms the basis for the interpretation of standard data. This assessment of the upper extremities is more complicated due to limb dominance, particularly in athletes who practice sports involving predominantly unilateral use of muscles (29).

Usually, a $5 \%$ to $10 \%$ maximum strength difference between limbs is considered to be normal (14). Previous studies have shown greater IR strength in professional, college and high school baseball pitchers. Nevertheless, although these authors have identified these differences as significant, they have not revealed their actual values (30).

Our results have shown an average difference of $3 \%$ between shoulder internal rotators. This result becomes even more interesting when we consider the results of the comparison of the shoulder ER, for which a difference of about $2 \%$ was found. Previous studies with baseball and tennis players have also failed to find major differences between the shoulder external rotators $(28,30)$. In spite of that, we note that the strength displayed by the participants of this study was lower than that found in previous studies conducted with volleyball players (31). This shows that, although there is a good balance between sides, swimmers have weaker shoulder ER and IR when compared with athletes of other sports.

Thus, we cannot say that swimming provides optimal balance of the glenohumeral joint, especially when we analyze the ER/IR ratios found in this study. We can see that only the non-dominant limb (i.e., the left arm) showed an ER/IR ratio within the acceptable range, and, even so, only with a small margin of reliability.

In studying the literature, we found two interesting explanations for these occurrences. Swimmers perform up to $2,500 \mathrm{arm}$-stroke cycles per day $(4,32)$. This excessive movement of the glenohumeral joint leads to a wearing of the static shoulder stabilizers (28), which, in turn, overloads the dynamic shoulder stabilizers, resulting in fatigue of these stabilizers and muscle imbalance. Another interesting fact is that some papers have been discussing the idea that swimming is not a sport of symmetrical proportions $(9,16,33)$, i.e., the movements made during swimming may lead to muscle imbalances due to the predominant unilateral use of some muscles.

Sports practice is beginning earlier and earlier. This may result in the adoption of patterns that are harmful 
to an individual's health, predisposing him/her to injuries (34).

Early diagnosis of changes resulting from sports training and the adoption of effective preventive measures can prevent the occurrence of injuries and contribute to increase athletic performance.

Several studies have assessed the shoulder muscles in swimmers (1, 3 - 9, 15, 16, 25, 32, 33). Nevertheless, in Brazil, only a few studies have been conducted in order to identify changes in the shoulders of elite level swimmers. Thus, the outcome of this study could contribute to the prevention of injuries from a fast growing sport in our nation.

We believe that concurrent physical therapy can be an important prophylactic means of preventing imbalances resulting from swimming and reestablishing muscle balance, especially of the shoulder.

\section{Conclusion}

The results of this research revealed that the swimmers had lower internal rotator strength in the left shoulder, and lower ER/IR strength ratio in the right shoulder. These data may serve as reference for other groups of swimmers and for comparisons with related studies of other sports. As a suggestion for further studies, we emphasize the importance of using a prospective, controlled, longitudinal design to promote a better understanding of the shoulder rotator strength in swimmers.

\section{References}

1. Ramsi M, Swanik KA, Swanik CB, Straub S, Mattacola C. Shoulder-rotator strength of high school swimmers over the course of a competitive season. J Sport Rehabil. 2004;13(1):9-18.

2. Ejnismann B, Monteiro GC, Uyeda LF. Ombro doloroso. Einstein. 2008;6(Suppl 1):S133-7.

3. Richardson AB. Manual de Medicina Esportiva. 1st ed. São Paulo: Manole; 2002.

4. Pink M, Tibone E. The painful shoulder in swimming athletes. Orthop Clin North Am. 2000;31(2):247-61.

5. Bak K. Nontraumatic glenohumeral instability and coracoacromial impingement in swimmers. Scand J Med Sci Sports. 1996;6(3):132-44.
6. McMaster WC, Troup J. A survey of interfering shoulder pain in United States competitive swimmers. Am J Sports Med. 1993;21(1):67-70.

7. Beach ML, Whitney SL, Dickoff-Hoffman SA. Relationship pf Shoulder flexibility, strength, and endurance to shoulder pain in competitive swimmers. J Orthop Sports Phys Ther. 1992;16(6):262-8.

8. Cohen M, Abdalla RJ, Ejnisman B, Schubert S, Lopes AD, Mano KS. Incidência de dor no ombro em nadadores brasileiros de elite. Rev Bras Ortop. 1998;33(12):930-2.

9. Shapiro C. Swimming. In Shamus E, Shamus J. Sports Injury Prevention \& Rehabilitation. New York: McGrawHill; 2001. p. 105-54.

10. Brown LP, Niehues SL, Harrah A, Yavorsky P, Hirshman HP. Upper extremity range of motion and isokinetic strength of the internal and external shoulder rotators in major league baseball players. Am J Sports Med. 1988;16(6):577-85.

11. Scoville CR, Arciero RA, Taylor DC, Stoneman PD. End range eccentric antagonistic/concentric agonist strength ratios: a new perspective in shoulder strength assessment. J Orthop Sports Phys Ther. 1997;25(3):203-7.

12. Hopkins JT, Ingersoll CD. Arthrogenic muscle inhibition: a limiting factor in joint rehabilitation. J. Sport Rehabil. 2000;9(2):135-59.

13. Cornu C, Nordez A, Bideau B. Shoulder rotators electromechanical properties change with intensive volleyball: A pilot study. Int J Sports Med. 2009;30(12):857-62.

14. Ohkoski Y, Yasuda K, Kaneda K, Wada T, Yamanaka M. Biomechanical analysis of rehabilitation in the standing position. Am J Sports Med. 1991;19(6):605-11.

15. Bak K, Magnusson DP. Shoulder strength and range of motion in symptomatic and pain free elite swimmers. Am J Sports Med. 1997;25(4):454-9.

16. Gozlan G, Bensoussan L, Coudreuse J-M, Fondarai J, Gremeaux V, Viton JM, et al. Isokinetic dynamometry measurement of shoulder rotation strength in healthy elite athletes (swimming, volleyball, tennis): comparision between dominant and nondominant shoulder. Ann Readapt Med Phys. 2006;49(1):8-15.

17. Vasconcelos EE. Confecção de um protótipo para avaliação das forças musculares do ombro [master's thesis]. São Carlos (Brazil): Universidade de São Paulo; 2005. Portuguese. 
18. Centers for Disease Control and Prevention (CDC). Healthy Weight. About Adult BMI. 2011 [cited 2015 May 24]. Available from: URL: http://tinyurl.com/aol69m.

19. Sousa O, Ribeiro F, Leite M, Silva F, Azevedo AP. Efeito da posição da omoplata na força máxima isométrica de flexão do ombro. Rev Port Cienc Desp. 2007;7(2):183-8.

20. Leite RC, Nonaka PN. Análise da influência do treinamento de flexibilidade sobre a força muscular em indivíduo jovem sedentário - estudo de caso. RBPFEX. 2009;3(15):302-11.

21. Schneider P, Henkin S, Meyer F. Força muscular de rotadores externos e internos, de membro superior em nadadores púberes masculinos e femininos. R Bras Ci e Mov. 2006;14(1):29-36.

22. Andrade RP, Silva ES, Vieira JS. Avaliação da Força dos Rotadores Externos e Internos do ombro em atletas de voleibol. Rev Bras Ortop. 1996;31(9):727-30.

23. Mendonça LM, Bittencourt NFN, Anjos MTS, Silva AA, Fonseca ST. Avaliação muscular isocinética da articulação do ombro em atletas da Seleção Brasileira de voleibol sub-19 e sub-21 masculino. Rev Bras Med Esporte. 2010;16(2):107-11.

24. Siqueira CM, Pelegrini FR, Fontana MF, Greve JM. Isokinetic dynamometry of knee flexors and extensors: comparative study among non-athletes, jumper athletes and runner athletes. Rev Hosp Clin Fac Med Sao Paulo. 2002;57(1):19-24.

25. Swanki KA, Swanki CB, Lephart SM. The effects of functional training on strength and incidence of injury in intercollegiate swimmers. J Sport Rehabil. 2002:11(2):140-54.

26. Ellenbecker TS, Davies GJ. The application of isokinetics in testing and rehabilitation of the shoulder complex. J Athl Train. 2000;35(3):338-50.

27. Alderink GJ, Kuck DJ. Isokinetic shoulder strength of high school and college-aged pitchers. J Orthop Sports Phys Ther 1986;7(4):163-72.

28. Hiemstra LA, Kirkley AM. Shoulder Instability in Female Athletes. Sports Med Arthrosc. 2002;1:50-7.

29. Ellenbecker TS. A total arm strength isokinetic profile of high skilled tennis players. Isokinet Exerc Sci. 1991;1(1):9-21.
30. Wilk KE, Andrews JR, Arrigo CA, Keirns MA, Erber DJ. The strength characteristics of internal and external rotator muscles in professional baseball pitchers. Am J Sports Med. 1993;21(1):61-6.

31. Lippitt SB, Vanderhooft JE, Harris SL, Sidles JA, Harryman DT, Matsen FA. Glenohumeral stability from concavitycompression: a quantitative analysis. J Shoulder Elbow Surg. 1993;2(1):27-35.

32. Bak K. Nontraumatic glenohumeral instability and coracoacromial impingement in swimmers. Scand J Med Sci Sports. 1996;6(3):132-44.

33. Meliscki GA, Monteiro LZ, Giglio CA. Avaliação postural de nadadores e sua relação com o tipo de respiração. Fisioter Mov. 2011;24(4):721-8.

34. Akachi, Hanai PM. A influência do treinamento competitivo do futsal na postura de atletas entre 9 e 16 anos. Rev Fisioter. 2001;8(2):97.

Received in $03 / 25 / 2013$ Recebido em 25/03/2013

Approved in 08/19/2015 Aprovado em 19/08/2015 